\title{
"The Momentous Gravity of the State of Things Now Obtaining": Annoying Westphalian Objections to the Idea of Global Governance
}

Timothy W. Waters

Indiana University Maurer School of Law, tiwaters@indiana.edu

Follow this and additional works at: https://www.repository.law.indiana.edu/ijgls

Part of the International Law Commons, and the Law and Politics Commons

\section{Recommended Citation}

Waters, Timothy W. (2009) "'The Momentous Gravity of the State of Things Now Obtaining": Annoying Westphalian Objections to the Idea of Global Governance," Indiana Journal of Global Legal Studies: Vol. 16 : Iss. 1 , Article 3.

Available at: https://www.repository.law.indiana.edu/ijgls/vol16/iss1/3

This Symposium is brought to you for free and open access by the Law School Journals at Digital Repository @ Maurer Law. It has been accepted for inclusion in Indiana Journal of Global Legal Studies by an authorized editor of Digital Repository @ Maurer Law. For more information, please contact rvaughan@indiana.edu.

\section{$\Psi$}

JEROME HALL LAW LIBRARY

INDIANA UNIVERSITY

Maurer School of Law
Bloomineton 


\title{
"The Momentous Gravity of the State of Things Now Obtaining": Annoying Westphalian Objections to the Idea of Global Governance
}

\author{
Timothy William Waters*
}

\begin{abstract}
Are there situations in which otherwise attractively complex, sub-and cross-national networks are unlikely to replace the hoary old Westphalian state? Perhaps, but whatever the answer, global governance as a discipline seems to have a hard time fully considering the question. One of the problems with operationalizing global governance may be the simultaneous profligacy and poverty of the idea itself: its definitional overemphasis on change and consequent inattention to the state's capacity to reconstitute its core functions and thus to achieve a predictable continuity. As a result, for all the excellent work done under its name, global governance as a unifying concept may actually contribute very little, and be less than the sum of its parts. Thinking about limits is not necessarily skepticism about the processes that collectively constitute global governance, but a way to give more meaningful shape to ideas which, as yet, are as problematically defined as they are fashionable.
\end{abstract}

\section{A Post-Westphalian Moment between the Entrée and Dessert}

Often the most valuable moments at a conference take place away from itconversation during the breaks, often over dinner or drinks. So as I cut into my

*Associate Professor of Law, Indiana University Maurer School of Law - Bloomington. J.D. 1999, Harvard Law School; M.I.A. 1998, Columbia University; B.A. 1989, University of California, Los Angeles. Thanks to participants in the conference for their comments on my presentation, from which this paper derives, and to Professor Hannah Buxbaum, Rachel Guglielmo, Professor Christiana Ochoa, and Dr. Brian Shoup for their comments on drafts of this paper. 
steak, or perhaps it was salmon, I listened to a fellow attendee expound on the ways Argentina is constrained by the changes and forces on which the case for global governance-the subject of our conference-is built. And then he concluded: "Argentina is just an actor like any other."

I have no metaphysical awe of the Argentine Republic's sovereignty-one of my earliest political memories is of the Falklands War-but this struck me as profoundly incorrect. I could think of no corporation, non-governmental organization, union, or other non-state actor whose capacities come close to those of this mid-level power.' Yes, Argentina is constrained; it is just one player-a tremendously powerful, resourceful player. And it is not, of course, the only one.

Yet this comment was consistent with ones I heard throughout the conference-another attendee, for example, predicted the state as we know it would not be around in fifty years-and would hardly be unprecedented in any discussion of global governance. ${ }^{2}$ Statements of faint praise for the power of states-"still relevant," with the implication "barely" or "but not for long"- suggest that there already are or soon will be other, more decisive actors. This strikes me as a problematic position-but more, as one that might indicate something problematic in the framework out of which such analysis arises, which is to say the framework of global governance: an orientation, a perspective, and ultimately a self-definition

1. Argentina's GDP is over $\$ 520$ billion. Its annual budget is $\$ 61$ billion; a few companies have larger revenues, but not many. Argentina has an enviable business model, extracting taxes from millions of individuals and corporate entities without paying taxes on its own enormous holdings. It administers a massive array of educational and cultural enterprises. In 1982, it launched a naval invasion across hundreds of miles of ocean. It has defaulted on its foreign debt five times. Argentina has votes in the U.N. and international organizations. Admittedly, Argentina is more powerful than most states, though this only highlights the ambition in calling it "just another actor." See CIA World Factbook: Argentina, https://www.cia.gov/library/publications/the-world-factbook/print/ar.html (last visited Nov. 8, 2008) (discussing Argentina's economy, government, and military); Argentina's Debt Restructuring: A Victory by Default?, ECONOMIST, Mar. 5, 2005, at 12 (discussing Argentina's $\$ 81$ billion debt default in 2001), available at http://www.economist.com/business/displayStory.cfm?story_ id $=3715779$ (abstract).

2. See, e.g., A. Claire Cutler, Critical Reflections on the Westphalian Assumptions of International Law and Organization: A Crisis of Legitimacy, 27 REv. INT'L STUD. 133, 133 (2001) ("The actors, structures, and processes identified and theorized as determinative by the dominant approaches to the study of international law and organization have ceased to be of singular importance."); Susan Strange, The Declining Authority of States, in The Global Transformations Reader 148, 148-49 (David Held \& Anthony McGrew eds., 2000) ("Today it seems that the heads of governments may be the last to recognise that they ... have lost the authority over national societies and economies that they used to have .... [T] he impersonal forces of world markets . . .are now more powerful than the states to whom ultimate political authority ... is supposed to belong."). 
that privileges proofs of change over continuity, and that is therefore, in some endemic way, susceptible to the risks of fahionability.

I was skeptical. Still, I finished my dinner; I sat through the conference. I enjoyed both: learned a lot and ate well. I am still skeptical.

\section{Does This Make Me Look Global? A Problem of Interpretation}

Every era has its fashions, every decade its fads. These are not trivial; the character of the times is best remembered by its style. Some fashions-abandoning corsets, adopting casual Fridays-reflect shifts in power and social roles. And taken together, ephemeral fashions may not only mark but constitute humanity's transformations. Perhaps we confront such a moment now, when something fashionable proves foundational, when the trendy resolves into a trendline. Perhaps the idea of global governance-which is undeniably fashionable ${ }^{3}$-is also world-historical. Certainly global governance, and the changes driving it, merit serious consideration; as the same text that provides my title notes-admittedly, in a somewhat different context- "wise men are discussing it; practical men are proposing schemes; popular meetings, legislatures, and rulers of nations are all busied with it-actually there is no question which has taken deeper hold on the public mind."4 In the moment, of course, it is so hard to know. Still, it is all very exciting

Now, a concern with faddishness might seem misplaced: normally we academics are not famous for being the most fashion-forward members of society. And certainly, whatever marginal influence a stylish concern with change-for-change'ssake might have cannot explain the sober and useful conclusions global governance theorists reach. Few theorists actually believe the state is going to wither away in favor of disaggregated networks (though as recently as a decade ago, that was an

3. See Benjamin J. Cohen, International Finance, in Handbook of InTERnational Relations 429, 442 (Walter Carlsnaes et al. eds., 2002) (discussing "the newly fashionable concept of Global Governance, which over the past decade has attracted increasing attention from IR scholars, particularly in Europe"); Michael Mann, Has Globalization Ended the Rise and Rise of the Nation-State?, in The Global Transformations Reader, supra note 2, at 136 ("The human sciences seem full of enthusiasts claiming that a new form of human society is emerging.").

4. His Holiness Pope Leo XIII, Rerum Novarum (May 15, 1981), available at http://www.vat ican.va/holy_father/leo_xiii/encyclicals/documents/hf_l-xiii_enc_15051891_rerum-novarum_ en.html ("The momentous gravity of the state of things now obtaining fills every mind with painful apprehension; wise men are discussing it; practical men are proposing schemes; popular meetings, legislatures, and rulers of nations are all busied with it-actually there is no question which has taken deeper hold on the public mind.") [hereinafter Rerum Novarum]; see also infra note 46. 
easier view to come across) - indeed the great majority either do not think anything of the kind ${ }^{5}$ or perceive a very different trajectory. In fact, I really must take the awkward step here of stating, as clearly and inartfully as I can, that I am in no way criticizing the quality and seriousness of writing that goes under the heading global governance. The articles in this volume are themselves evidence of the quality, rigor, and thoughtfulness that much of this work evinces; several of these pieces make real contributions to understanding how components of our shared local and global communities are constructed and ordered, and one can say the same about much global governance literature. Indeed, as I will suggest, when a concept is defined as broadly as global governance is, it would be hard to imagine that it would not encompass much quality scholarship.

Yet for all the excellent individual contributions, I continue to wonder if there might not be something joining them that, taken as a whole, merits closer, critical scrutiny. An orientation towards change, and in particular assumptions about the state's malleability as an effective governing agent-a malleability often expressed in the state's relative decline in favor of other sources of legitimacy, authority, and power-defines the study of global governance, or at least drives us to call the many different things we are studying by that name. Is there not something risky in orienting a program of research around the study of change, but not, to the same degree, of continuity? My concern is directed not at what global governance theorists have written, but what they have not-at the tendency, discernible in its definition, that makes global governance (whether as discipline, theory, or concept) in some problematic way less than the sum of its excellent parts. ${ }^{6}$

In raising concerns about global governance's orientation towards change, I am not denying that profound changes have occurred in recent decades, the last century, or last few centuries, changes which can be plausibly labeled "globalization." Contacts between individual humans, economic activity across frontiers, and interactions among states have all increased tremendously, while novel forms of decision making and participation have arisen (labor unions, non-governmental organizations, global corporations, democracy, the state itself) and spread across the globe, unifying and homogenizing political experience. This seems un-

5. That same author who predicted the end of the state as we know it in fifty years notes in his article, "[h]owever, [that] sharing power does not render states obsolete or impotent." N. Brian Winchester, Emerging Global Environmental Governance, 16 IND. J. Global LeGAL STUD. 7, 22 (2009).

6. I am speaking about global governance theory in highly general terms, but for a specific purpose: to highlight the ways in which the concept produces, or encourages, a general sensibility or perspective in its practitioners. It would be impossible, and wrong, to speak of this as a quality affirmatively attaching to each and every instance of global governance research in some concrete way. 
deniable. The question, though, is does all this indicate fundamental change in the structures that have regulated human activity in the modern era? Specifically, does all this prove, or predict, a shift from a system dominated by states to a disaggregated model of the kind that global governance appears definitionally to describe, even if only as the aggregate of many smaller shifts?

As I said, I am skeptical: I think there is a real risk that global governance conflates many interesting developments into one theory (whose unifying feature is change) assigning that theory powers of transformation and justification that it does not necessarily possess and which we might logically expect it would not. The risk inherent in global governance as an analytical frame may be the simultaneous profligacy and poverty of the idea itself: its elastic definition, privileging assumptions about what the state has been, or might be, reduced to, and a concomitant shortage of rigorous engagement with evidence of continuity. Skeptical in other words, not about change, but about its interpretation: does the concept of global governance afford us a robust new mode for understanding of our world, or have we purchased the intellectual equivalent of a pair of really big sunglasses?

This little essay suggests three things. First, problems of definition may continue to plague discussion of global governance even as it moves forthrightly into the future. Second, global governance as a theory may overstate the challenges to the state and the robustness of alternatives, to the degree it overemphasizes the effects of recent change and fails fully to incorporate predictably sticky elements in states' functional capacities. And third, this overstatement in turn creates a risk that global governance as an organizing concept will act more as an aggregator than a generator of insights, contributing little to the otherwise excellent individual work conducted under its rubric. But I will only suggest: I do not intend a comprehensive critique, but only to note some obvious points that the discipline may be structurally inclined to discount. Thinking about the limits is not necessarily skepticism about all the changes that constitute global governance, but instead it is a way to give useful shape to a set of ideas and processes which, as yet, are as inchoate as they may be undeniable.

Finally, this article arises from a conference and makes use of its papers, presentations, and the found bits of conversation that make any conference valuable. Such things are hard to footnote, but the kinds of questions that arise from taking global governance seriously - the obvious critiques that arise the moment one really does-are going to be asked again, at other conferences, with the quality of a

7. Cf. Sarah Sands, Why Do Women Love Bug Eye Sunglasses?, DaILY MAIL, June 15, 2006, available at http://www.dailymail.co.uk/femail/article-390765/Why-women-love-bug-eye-sunglasses.html. 
set piece, even though they are serious, unsettled, annoying, and likely to be so for as long as global governance remains fashionable.

\section{The Problem of Defining Global Governance, and Defining It as We Do}

Many scholars have noted problems with defining global governance, ${ }^{8}$ and that is unsurprising, because global governance-at least the study and discussion of it-is an enterprise whose contours may best be defined by their elasticity. Certainly, the range of subjects proffered as instances of global governance--private lawsuits, satellite consortia, business cartels, constitutional courts, constitutional design, non-governmental organization activism and accountability mechanisms,

8. Winchester gives an example: "But what is global governance? James N. Rosenau has clearly framed the question.

Does it refer to a central authority that can exercise control over far-flung situations on a global scale? Or is it limited to the exercise of authority in particular situations, such as environmental threats or outbreaks of widespread violence, which may be global in scope and especially dire? Or does it connote the sum of all diverse efforts of communities at every level to move towards goals while preserving their coherence from one moment to the next?

Winchester, supra note 5, at 18 (quoting James N. Rosenau, Governance in a New Global Order, in The Global Transformation Reader 223, 224 (David Held \& Anthony McGrew eds., 2d ed. 2003)); see also Klaus Dingwerth \& Philipp Pattberg, Global Governance as a Perspective on World Politics, 12 Global Governance 185, 185 (2006) (citations omitted):

In contemporary academic debate about world politics, "global governance" is all over the place.... Whether it is observable phenomena ...or the ubiquitous talk about global governance itself, almost any process or structure of politics beyond the state-regardless of scope, content, or context-has within the last few years been declared part of a general idea of global governance. What this idea is about is a question rarely addressed. Instead, most of the works on global governance stop short of pondering why they are using the newly coined termrather than, say, more old-fashioned terms such as international organization or international politics - and what is implied by its use. On the other hand, those who do ask, "What is global governance?" are likely to come to the conclusion that "'Global Governance' appears to be virtually anything."

Id.; Tanja A. Börzel \& Thomas Risse, Public-Private Partnerships: Effective and Legitimate Tools of International Governance, in Complex Sovereignty: Reconstituting Political Authority in the Twenty-First Century (Edgar Grande \& Louis W. Pauly eds., 2005); Elke Krahmann, National, Regional, and Global Governance: One Phenomenon or Many? 9 Global Governance 323 (2003). 
and pipeline negotiations - confirms either the capaciousness or the cacophony of global governance.

It is hard to define things. Yet without agreement or a sense of scope, it is not clear that we are even dealing with a coherent phenomenon, which makes it difficult to move on to best practices. Still, I think there is a coherent definition of global governance, though I am not sure it helps make the case for the concept: What best unites the many instances of global governance, definitionally, is a particular temporal interpretation-a claim about recent or current change- that in turn may have consequences for the clarity, robustness, and directionality of research.

"Governance" might be narrowly described as legitimated decision making and execution. ${ }^{9}$ But this brings governance uncomfortably close to the word it clearly mimics and sidesteps ${ }^{10}$ strangling at birth the idea that something other than a government might have a role in governing. A broader definition-which better describes the mainstream of the discipline ${ }^{11}$ — captures richness beyond the formal, ${ }^{12}$ but also risks succumbing to its lexical laxity: the soon acts of Parliament, the peasant risings, the subtle conventions for riding elevators, and the rules

9. Cf. Order in the Jungle, Economist, Mar. 15, 2008, at 83,83 (defining governance as "political accountability and the quality of bureaucracy as well as the rule of law"). The United Nations Development Program defines "good governance" as "the responsible exercise of political, economic and administrative authority in the management of a country's affairs at all levels." Aide Memoire, International Conference on Governance for Sustainable Growth and Equity, U.N. Dev. Program, N.Y., (July 28-30, 1997), available at http://mirror.undp. org/magnet/icg97/MEMOIR2.HTM. Minus "responsible," this would presumably define "governance."

10. See Commission on Global Governance, Our Global Neighborhood: The Report of THE COMmission on Global GovernanCE, at xvi (1995) ("As this report makes clear, global governance is not global government.").

11. Id. at 2 ("Governance is the sum of the many ways individuals and institutions, public and private, manage their common affairs. It is a continuing process through which conflicting or diverse interests may be accommodated and co-operative action may be taken. It includes formal institutions and regimes empowered to enforce compliance, as well as informal arrangements that people and institutions either have agreed to or perceive to be in their interest."); see also Gunther Teubner, Societal Constitutionalism: Alternatives to State-Centred Constitutional Theory?, in Transnational GoverNANCE AND CONSTITUTIONAlism 3, 16 (Christian Joerges et al. eds., 2004) ("Law-making also takes place outside the classical sources of international law, in agreements between global players, in private market regulation by multi-national concerns, internal regulations of international organisations, inter-organisational negotiating systems, world-wide standardisation processes that come about partly in markets, partly in processes of negotiation among organisations.").

12. See also Myres S. McDougal \& Harold D. Lasswell, The Identification and Appraisal of Diverse Systems of Public Order, 53 AM. J. INT'L L. 1 (1959) (discussing the shortcomings of formal conceptions of government); $c f$. LUNG-CHU CHEN, AN INTRODUCTION TO CONTEMPORARY INTERNATIONAL LAW: A Policy-Oriented Perspective 14 (1989) (describing the New Haven School's rejection of formalist analysis of how law works). 
for Kosher meat are all governance. ${ }^{13}$ Not that there is anything wrong with that; like Molière's Bourgeois Gentilhomme, you may be delighted to discover you have been engaged in governance all your life.

Either way, governance, properly considered, is atemporal; it describes a general theory, reminding us that formal institutions never fully represent human complexity. "Global," in turn, suggests a focus on levels either hierarchically above or at least different from the state. ${ }^{15}$ But as it is most commonly used in connection with "governance," "global" introduces a potentially problematic temporal claim. It would certainly be possible to conceive of "global governance" as an atemporal analytical approach-a methodological commitment to engaging complexity and avoiding exclusively statist interpretations - that one could apply at any point in history. ${ }^{16}$ Yet despite the availability of such a perspective, what best unites the members of the defined set "global governance" is the temporal variant: governance is changing under conditions of interconnectedness that are happening now. ${ }^{17}$

13. Cf. Commission on Global Governance, supra note 10, at 2-3 (giving examples ranging from "a neighborhood cooperative formed to install and maintain a standing water-pipe," a stock exchange, NGOs, the global capital market, and private associations of beet farmers).

14. See Thomas G. Weiss, Governance, Good Governance and Global Governance: Conceptual and Actual Challenges, in THe Global Governance Reader 68, 68 (Rorden Wilkinson ed., 2005) ("'Governance' is now fashionable, but the concept is as old as human history."). "Governance"-minus the global, but with a domestic focus-has a long pedigree in political science. Dingwerth \& Pattberg, supra note 8 , at 188.

15. Cf. Dingwerth \& Pattberg, supra note 8, at 188. ("[G]lobal can at least refer to two different spheres - the toplevel scale of human activity or the sum of all scales of activity[.]").

16. So, for example, Rosenau's description of "global governance. . .conceived to include systems of rule at all levels of human activity-from the family to the international organization-in which the pursuit of goals through the exercise of control has transnational repercussions[,]" could plausibly frame research into such systems in any age. James N. Rosenau, Governance in the Twenty-first Century, 1 Global Governance 13 (1995), cited in Dingwerth \& Pattberg, supra note 8, at $189 \mathrm{n} .18$. When I looked, Wikipedia defined "global governance" in fairly atemporal terms as "the political interaction of transnational actors aimed at solving problems that affect more than one state or region when there is no power of enforcing compliance." Wikipedia, Global Governance, http://en.wikipedia .org/wiki/Global_governance (last visited Nov. 8, 2008). Wikipedia is a derivative source, but I like to use it because it is, in its way, a social analogue for the kinds of challenges and processes global governance entails. And of course, you can change it.

17. Rosenau, again, defines global governance as "an irreversible process [where] authority is increasingly disaggregated, resulting in a system of global governance that comprises more and more centres of authority in every corner of the world and at every level of community." Winchester, supra note 5 , at 18 . This removes "global" from the atemporally methodological and places it firmly in the realm of outcome obtained under processes presently (if to Rosenau irreversibly) underway. 
Typical assays at defining global governance--even if they share little elsefrequently share this temporal orientation: ${ }^{18}$

- "a new and as yet undefined global order, characterized in part by porous borders and power sharing amongst states, non-state actors, and new geographic and/or functional entities."19

- collective efforts to identify, understand, or address worldwide problems that go beyond the capacity of individual states to solve. ${ }^{20}$

- a "sequel to Westphalia."21

Despite the observed diffuse character of global governance, we might distill from these or similar definitions some core themes:

- Problems exist which by their nature require broader or more collective decision making than the state affords;

- There is an absence of hierarchical structures to address those problems; but

- The evolving responses are complex and systemic in nature;

- Global governance is not simply a new way of understanding the operation of society. It is a claim that specific changes are happening now;

- This shift represents a new era, in which state sovereignty is altered and sometimes reduced in favor of a flourishing of sources, authorities and actors; and

- This new era is not Westphalia.

On this last point: When theorists describe global governance as a systemic shift, the system they are shifting from is the Westphalian. The remembered Westphalian system was marked by the factual existence of (and normative support for) self-legitimating states, whose people and processes were their own concern. Of course, the Westphalian system was much more than apotheosized

18. Here again, as throughout, I am not asserting some specious uniformity among theorists-I am only speaking of tendencies and implicit commonalities; actual instantiations of theory and policy may produce highly variable outcomes, and, as I have noted, an atemporal orientation towards the global is certainly available.

19. Winchester, supra note 5.

20. Wikipedia, supra note 16 (citing Thomas G. Weiss \& Ramesh Thakur, The UN and Global Governance: An Idea and its Prospects (forthcoming 2008)); $c f$. U.N. Econ. \& Soc. Council [ECOSOC], Comm. of Experts on Pub. Admin., Definition of Basic Concepts and Terminologies in Governance and Public Administration, II 15, U.N. Doc. E/C.16/2006/4 (Jan. 5, 2006), available at http:// unpanl.un. org/intradoc/groups/public/documents/un/unpan022332.pdf.

21. Richard Falk, Revisiting Westphalia, Discovering Post-Westphalia, 6 J. EтHics 311, 345 (2002). 
sovereignty and non-interference; with its principle of cuius regio eius religio, ${ }^{22}$ its provisions for free commercial traffic, and its norms of conquest, Westphalia was a model of global governance too-an international system for solving problems in the absence of global government. ${ }^{23}$ Nor was Westphalia static; its norms were refined, abandoned, and accreted from the very beginning, as indeed some global governance theorists recognize. ${ }^{24}$ The post-Westphalian world began the day after Westphalia was signed, ${ }^{25}$ and the late Westphalian state was far more similar to our post-Westphalian condition than to its earliest incarnations. ${ }^{26}$ All this is obvious enough, and I think most global governance scholarship is fully consistent with these obvious propositions. Still, even measured analysis that in no way anticipates the disappearance of the state often takes it as evident that "the Westphalian system" is failing conceptually and even practically, and that global governance represents its replacement. ${ }^{27}$ Here we encounter a first consequential

22. This flexible regional norm applied only to Christian sovereigns.

23. Westphalia is ordinarily — and inaccurately -interpreted as the apotheosis of an impenetrable state sovereignty. On the contrary, by providing express guarantees for the practice of religion within each state, Westphalia ordered the internal workings of each state by all, while also lifting wartime trade barriers and navigational restrictions on the Rhine. Treaty of Westphalia arts. LXIX, LXX, \& LXXXIX, Oct. 24, 1648, available at http://avalon.law.yale.edu/17th_century/westphal.asp. See generally Leo Gross, The Peace of Westphalia, 1648-1948, 42 AM. J. INT'L L. 20 (1948). Westphalia also preserved norms of warfare and conquest, which, if one thinks about it, are not conducive to territorial sovereignty. Full territorial integrity is a product of the post-WWII era and is one reason why the "intrusive" project of human rights arises at the same time.

24. Cf. Stephen D. Krasner, Compromising Westphalia, in The Global Transformations READER, supra note 2, at 124, 124-35. "The Westphalian model has never been more than a reference point or a convention; it has never been some deeply confining structure from which actors could not escape." Id. at 124 .

25. Westphalia is a pastiche: Münster and Osnabrück, signed in 1648, and the Treaty of the Pyrenees, signed in 1659 . Westphalia's central innovation expanded a religious recognition principle from the Peace of Augsburg, signed in 1555, and while those who signed Münster in 1648 contemplated an eventual Franco-Spanish treaty (mentioned in Articles IV and V), they could not have known it would take another eleven years. It all sounds so messy and complex, not like "Westphalia" at all.

26. The early Westphalian state: was religious, agricultural, monarchical and feudal; possessed a minimal state apparatus; lacked concepts such as secularism, separation of powers, professional bureaucracy, or human rights; and used Latin as a language for system-wide communication.

27. See, e.g., Cutler, supra note 2, at 133 ("Westphalian-inspired notions of state-centricity, positivist international law, and 'public' definitions of authority are incapable of capturing the significance of non-state actors, [like transnational corporations and individuals], informal normative structures, and private, economic power in the global political economy."); see also SEYOM BROWN, International Relations in a Changing Global System: Toward a Theory of the World POLITY 107-18 (2d ed. 1996) (describing incongruities between the state system and developments in ecology and economics). 
instance of a definition weighted towards change that may exercise a distorting effect on the broader direction of research.

For now, though, we should simply note this claim of systemic shift, as well as the frequent identification of global governance with relatively greater mass participation; though in some instances global networks may end up strengthening the state, in many other the process of solving complex, cross-border problems will also expand participation by individuals, corporations, NGOs, cultural groups, and other non-state actors. For many scholars, this is a positive enthusiasm, a project of political preference and advocacy; for others, it may be a thing to be guarded against, at least in specific instantiations, such as global jihad or the rise of multinational corporations. What these all share, though, is a perspective that privileges evidence of change particularly through moves towards greater complexity below, above, and between traditional states. ${ }^{28}$ Several papers at this conference sounded such themes. ${ }^{29}$

With this in mind, I put forward my own assay at what global governance's self-definition might be:

A broadly-defined array of changes in the distribution of authority, legitimacy, decision making and participation by individuals and organizations in ordering human society, in response to similarly broad changes to material, social, technological, and economic conditions. These changes center on the increasing interconnectedness and complexity of life and the concomitant inability of the existing state system (composed of territorially, jurisdictionally, hierarchically bounded units) adequately to respond. This leads to the formation or legitimation of disaggregated networks of sub- or cross-state communities as rule-producing and rule-enforcing actors. Global governance is therefore marked by simultaneous moves to higher and lower (or more decentralized) levels of functional organization than traditional states, and toward greater participation by individuals. The changes leading to global governance have

28. Cf. Dingwerth \& Pattberg, supra note 8 , at 191 ("In essence, global governance implies a multiactor perspective on world politics.").

29. See, e.g., Michael Ewing-Chow \& Darryl Soh, Pain, Gain, or Shame: The Evolution of Environmental Law and the Role of Multinational Corporations, 16 IND. J. GlobaL LEGAL STUd. 195 (2009); Faina Milman-Sivan, Representivity, Civil Society and the EU Social Dialogue, 16 IND. J. Global Legal Stud. 311 (2009); Miguel Schor, An Essay on the Emergence of Constitutional Courts, 16 IND. J. GLOBAL LEGAL STUD. 173 (2009); Winchester, supra note 5. 
been occurring over an indeterminate timeframe at least since industrialization, more so since the Second World War, and especially in recent decades. Global governance marks a significant shift from the Westphalian state-centered governance system.

This definition-which I hope reasonably captures the main themes that global governance scholarship shares without capturing too much else-places us in a position to consider the enormous problems inherent in talking about shifts in governing power: problems in identifying an historical baseline and describing a trajectory. I think it does this by demonstrating that the otherwise inchoate concept global governance has a discernible, and therefore contestable, core; the claim at its center is that, although we have never had a hierarchical global order and have always had complex systems to create order, problems requiring global coordination have increased and the capacity of states to handle those problems (and thus be positioned as the exclusive or predominant actors) has not kept pace. Global governance is not merely a theory about decision making in general; it is a claim that particular, consequential changes are happening now. That is clear enough. Is it true?

\section{Still Relevant: Looking Forward to Looking Back at the State}

Is the state system undergoing a radical transformation? Is something displacing its authority? Are there any limits- situations in which otherwise attractively complex, transnational, globalized networks are structurally unlikely to replace the hoary old Westphalian state? These are questions about the future. As global governance theorists acknowledge, states wield enormous influence in governance of the globe, ${ }^{30}$ but this fact does little to engage the debate, because given its focus on recent, novel change, global governance may best be understood as a prediction about effects of globalization that are often only beginning to be fully felt: the fact that only 5 percent of humanity has ever flown ${ }^{31}$ or that this is the first year more than half of us live in cities ${ }^{32}$ is irrelevant if one discerns the trend. ${ }^{33}$ I accept that, and move to the question of interpretation: might the best evidence for global governance be more ambiguous

30. See, e.g., Rosenau, supra note 16, at 13 ("The United Nations system and national governments are surely central to the conduct of global governance, but they are only part of the full picture.").

31. Worldwatch Institute, Vital Signs 2006-2007, at 68 (2006). Given the 1.9 billion fights taken annually in 2004, that is a lot of repeat customers: I have taken 28 fights this year so far.

32. Burkhard Bilger, The Long Dig, NEW Yorker, Sept. 15, 2008, at 63, 63 (citing U.N. population figures).

33. I do not mean globalization only affects those who travel or live in cities. See infra note 41. 
than it appears? I think the answer is possibly yes. That evidence reveals inconsistent baselines for claims about change over time and problematic assumptions about the state that may fail to account for its dynamism-problems, that is, arising out of the temporal, change-oriented definition of global governance.

\section{A. Do Changes Challenge the State System?}

On the standard account, profound changes in social and economic patterns challenge states' monopoly on governance. But mere change is not enough; it must be change that demonstrably alters the capacity of the present system of states (and their regimes) to govern. Consider technology: although some theorists have supposed that technological change would weaken the state's ability to exert certain forms of control, ${ }^{34}$ states are as likely to gain power from technological change as they are to lose it. In recent decades, technology has, on balance, enhanced gov-

34. See, e.g., Jessica T. Mathews, Power Shift, ForEIGN AFF., Jan.-Feb. 1997, at 50, 51 :

The most powerful engine of change in the relative decline of states and the rise of nonstate actors is the computer and telecommunications revolution, whose deep political and social consequences have been almost completely ignored. Widely accessible and affordable technology has broken governments' monopoly on the collection and management of large amounts of information and deprived governments of the deference they enjoyed because of it. In every sphere of activity, instantaneous access to information and the ability to put it to use multiplies the number of players who matter and reduces the number who command great authority. The effect on the loudest voice - which has been government's - has been the greatest.

By drastically reducing the importance of proximity, the new technologies change people's perceptions of community. Fax machines, satellite hookups, and the Internet connect people across borders with exponentially growing ease while separating them from natural and historical associations within nations. In this sense a powerful globalizing force, they can also have the opposite effect, amplifying political and social fragmentation by enabling more and more identities and interests scattered around the globe to coalesce and thrive.

.... Above all, the information technologies disrupt hierarchies, spreading power among more people and groups. In drastically lowering the costs of communication, consultation, and coordination, they favor decentralized networks over other modes of organization.... Governments, on the other hand, are quintessential hierarchies, wedded to an organizational form incompatible with all that the new technologies make possible.

Id. 
ernment capacity to monitor, ${ }^{35}$ control, ${ }^{36}$ and gather information ${ }^{37}$ on citizens and corporations in ways a cash and postal economy obscured. Claims that technology is rendering the state less central to governance also require a sophisticated calculus to identify the point at which technology began to dismantle, rather than build up the state; historically it was the technological and social innovation accompanying the Industrial Revolution which made the modern state (with its enormous powers to tax, keep records, organize military forces, and provide services) both possible and inevitable. ${ }^{38}$ When, and under what conditions, would technological development begin to produce a different effect?

Likewise, the flow of human beings across state frontiers-191 million

35. Most public areas of central London are under closed-circuit television camera surveillance. George Orwell, Big Brother is Watching Your House, MAIL ON Sun., Apr. 1, 2007, at 22, available at http://www.thisislondon.co.uk/news/article-23391081-details/George+Orwell,+Big+Brother+is+wa tching+your+house/article.do (noting the average person-presumably in Britain or London-is caught on camera 300 times daily). The Echelon satellite system allows several states (in a form of cross-border cooperation) to monitor large streams of international communication. See Federation of American Scientists Intelligence Resource Program, http:/www.fas.org/irp/program/process/ech elon.htm (last visited Nov. 8, 2008) (discussing Echelon system). The Global Earth Observation System of Systems (GEOSS) - mentioned in the conference as an example of global governance-is perhaps more parsimoniously understood as an instance of cooperation, controlled by states, of a very familiar kind. See Group on Earth Observations, http://www.earthobservations.org/about_geo.shtml (last visited Nov. 8, 2008).

36. China has effective technologies for blocking Internet use. See Human Rights Watch, Race to THE BotTom: CORPORATE COMPlicity IN CHINESE INTERnET CENSORSHIP (2006), available at http:// www.hrw.org/reports/2006/china0806/index.htm; Jonathan Zittrain \& Benjamin Edelman, Empirical Analysis of Internet Filtering in China, IEEE INTERNET COMPUTING, Mar. 2003, at 70, available at http://cyber.law.harvard.edu/filtering/china/ (more than 50,000 web sites are inaccessible from China); OpenNet Initiative, Internet Filtering in China, 2004-2005: A Country Study, http://opennet.net/ studies/china/ (last visited Sept. 29, 2008).

37. Recently the United States procured customer information from major telecommunications companies. Ellen Nakashima, Telecom Firms Helped with Government's Warrantless Wiretaps, WASH. Post, Aug. 24, 2007, at D3, available at http:/www.washingtonpost.com/wp-dyn/content/ article/2007/08/23/AR2007082302056.html.

38. See, e.g., Benedict Anderson, Imagined Communities: Reflections on the Origins and SPREAD OF Nationalism 114, 188-89 (rev. ed. 1991) (noting the role of technology in state development); Hsi-Huey Liang, The Rise of Modern Police and the European State System from METternich to tHE SECOND WORLd WAR (2002) (discussing the contributions of nineteenth century innovations to the development of modern police); THE Formation of NATIONAL STATES IN WESTERN EUROPE (Charles Tilly ed., 1975) (examining the events, processes, preconditions, and developments contributing to the establishment of powerful national states); CHARLES TILLY, CoERCION, CAPITAL AND EUROPEAN STATES, AD 990-1992, at 100 (1992) (discussing transferability of social innovation); Ronald Krebs, Hypotheses on War and Democracy: Clearing Away the Underbrush (Int'l Stud. Assoc., 2006), http://www.allacademic.com/meta/p98178_index.html (discussing theories about the relationship between modern warfare and the rise of both the modern states and mass democracy). 
migrants, ${ }^{39}$ another standard proof of changes to which states are ill-equipped to respond ${ }^{40}$--is 3 percent of the world's population. Even as a trend, it is disappointing to find the vast majority of people so sedentary. ${ }^{41}$ For those who do move, frontiers, immigration rules, and citizenship restrictions are ever-present proofs of the role states play in ordering human existence. ${ }^{42}$ It is still true, as Arendt pointed out, that statelessness is the most debilitating social condition. ${ }^{43}$ Nor is the present flow unprecedented; the nineteenth century had higher rates,${ }^{44}$ and despite a decades-long wave, the United States (99 percent of whose population is the result of an enormous migration over the last 516 years) has still not reached the level of foreign-born population it had prior to $1910^{45}$ - a date some would identify as a highwater mark of the Westphalian order.

The fact of change is not itself evidence of relative decline in states' capacity; an additional act of interpretation is necessary, one that takes seriously the identification of historical baselines that allow us to consider how unique present levels

39. International Organization for Migration, Global Estimates and Trends, http://www.iom .int/jahia/Jahia/pid/254/ (last visited Sept. 29, 2008) (citing data from U.N. Econ. \& Soc. Council [ECOSOC], Population Division, Trends in Total Migrant Stock: The 2005 Revision (Feb. 2006), http://www.un.org/esa/population/publications/migration/UN_Migrant_Stock_

Documentation_2005).

40. See, e.g., Catherine Wihtol de Wenden, The Frontiers of Mobility, in Migration Without Borders: Essays on the Free Movement of People 51, 59-60 (Antoine Pécoud \& Paul de Guchteneire eds., 2007) (questioning "the cohesion of the state and its role as the main protagonist in international relations").

41. An African farmer who never leaves his village is still profoundly affected by global economic forces-the "thick" globalization marking the present era. See Robert O. Keohane \& Joseph S. Nye Jr., Introduction, in GovernanCE IN a Globalizing World 7 (Joseph Nye \& John D. Donahue eds., 2000) ("'[T] hick' relations of globalization involve many relationships that are intensive as well as extensive: long-distance flows that are large and continuous, affecting the lives of many people."). I am only addressing the deployment of population movements themselves as evidence of challenges to classical governance models.

42. See Linda Bosniak, Citizenship Denationalized, 7 Ind. J. Global Legal Stud. 447 (2000); Catherine Dauvergne, Sovereignty, Migration and the Rule of Law in Global Times, 67 MOD. L. REv. 588,588 (2004) (arguing that migration controls are the "last bastion" of sovereignty but also that rule of law norms are constraining states' scope of action).

43. Hannah Arendt, We Refugees, in THE Jewish Writings 264, 273 (Jerome Kohn \& Ron H. Feldman eds., 2007).

44. Paul Hirst \& Grahame Thompson, Globalization and the History of the International Economy, in The Global Transformations Reader, supra note 2, at 274, 275-76.

45. Sam Roberts, Foreign-born Population Headed for Record in U.S., Researchers Say, INT'L HERALD TRIB., Feb. 12, 2008, at 6, available at http://www.iht.com/articles/2008/02/12/america/immig.php. 
of change are, if states have responded to similar challenges in the past ${ }^{46}$ and the valence changing conditions might have on the governing balance. A global governance theory that is, even implicitly, premised on the study of change risks mistaking mere change for proof of transformation in the international regime of governance-and thus becoming a circular proof of its own proposition that global governance is a meaningful analytical category.

\section{B. Evidence of Actually Existing Global Governance}

The case for global governance is based not only on states' diminished relative capacity but also on the rise of alternatives. Change creates space in which viable competitors arise: non-governmental organizations (NGOs), multilateral institutions, private law making. As the incredibly broad range of subjects broached at the conference suggests, ${ }^{47}$ global governance expresses itself in an incredibly broad range of ways - so broad, in fact, that it may not describe a coherent claim about displacement, fragmentation, or reconfiguration of state power across time.

\section{NGOs}

No field better demonstrates these problematic tendencies than analysis of NGOs as vectors of cross-national and sub-national governance ${ }^{48}$ - certainly, "global

46. $C f$. Rerum Novarum, supra note 4 ("That the spirit of revolutionary change, which has long been disturbing the nations of the world, should have passed beyond the sphere of politics and made its influence felt in the cognate sphere of practical economics is not surprising. The elements of the conflict now raging are unmistakable, in the vast expansion of industrial pursuits and the marvellous discoveries of science; in the changed relations between masters and workmen; in the enormous fortunes of some few individuals, and the utter poverty of the masses; the increased self reliance and closer mutual combination of the working classes; as also, finally, in the prevailing moral degeneracy."); His Holiness Pope John Paul II, Centesimus Annus (May 1, 1991), available at http://www .vatican.va/edocs/ENG0214/_P2.HTM.

47. I only note a few examples, which neither adequately address the rich diversity of global governance nor adequately show how those diverse instances proceed from the same problematic definitional framework.

48. See Margaret Keck \& Kathryn Sikkink, Activists beyond Borders: Advocacy Networks IN INTERNATIONAL Politics (1998) (discussing transnational advocacy networks); Steve Charnovitz, Two Centuries of Participation: NGOs and International Governance, $18 \mathrm{MICH}$. J. INT'L L. 183, 286 (1997) (discussing NGOs and international governance); Charlotte $\mathrm{Ku}$, Strengthening International Law's Capacity to Govern Through Multilayered Strategic Parnerships (Center on Law and Globalization, Research Paper No. 08-02, 2007), available at http://ssrn.com/abstract=1259215 (examining multiple layers at which international law functions). 
civil society" was a centerpiece of early global governance claims. ${ }^{49}$ One author notes that global NGOs now account for more expenditure than the U.N., excluding IMF and World Bank. ${ }^{50}$ Considering those organizations have a combined budget of just a few tens of billions of dollars ${ }^{51}$ (funded almost exclusively from state monies ${ }^{52}$ ), this simply reminds us that the international NGO sector is tiny in comparison with state outlays, ${ }^{53}$ and even that is funded in significant part by governments. ${ }^{54}$ Moreover, NGO participation in standard setting or institution building is not necessarily even governance in any novel sense; translated to the domestic sphere, it would be readily cognizable as lobbying aimed at pressuring states to act. ${ }^{55}$ In his excellent article, Brian Winchester notes that at the 1992 Earth Summit, which ushered in "a

49. Kenneth Anderson, Global Governance: The Problematic Legitimacy Relationship between Global Civil Society and the United Nations, (Washington College of Law Research Paper, 2008) http://papers.ssrn.com/sol3/cf_dev/AbsByAuth.cfm?per_id=235051.

50. Winchester, supra note 5, at 18.

51. Global Policy Forum, UN Finance, http://www.globalpolicy.org/finance/index.htm (last visited Nov. 12, 2008) ("The United Nations and all its agencies and funds spend about $\$ 20$ billion each year, or about $\$ 3$ for each of the world's inhabitants."); UNAUSA.org, Fact Sheet: United Nations Funding (May 2006), http://www.unausa.org/site/pp.asp?c=fvKRI8MPJpF\&b=667579/ (noting U.S. share of funding and arrears).

52. The United Nations does have exciting sidelines in retailing. See Global Policy Forum, United Nations Children's Fund-Sources of Income, http://www.globalpolicy.org/finance/tables/ special/unicef.htm (last visited Oct. 3, 2008) (displaying data that shows over 15\% of UNICEF's 2003 budget is from "Greeting Cards and Related Operations").

53. Global Policy Forum, supra note 51 (noting that U.N. spending "is a very small sum compared to most government budgets and it is just a tiny fraction of the world's military spending").

54. See, e.g., Elizabeth G. Ferris, The Role of Non-Governmental Organizations in the International Refugee Regime, in Problems of Protection: The UNHCR, Refugees, and Human Rights 117 (Niklaus Steiner et al. eds., 2003) (discussing growing NGO involvement in refugee protection). See generally Michael Szporluk, A Framework for Understanding Accountability of International NGOs and Global Good Governance, 16 IND. J. Global LeGal STUD. 339 (2009) (discussing criticisms of nongovernment based international organizations). Of course, public-private partnerships (with public funding) are, arguably, a form of global governance-just one that may do less to alter the broader outlines of statist dominance of the system than might appear.

55. See, e.g., Amy Pollard \& Julius Court, How Civil Society Organisations Use Evidence to Infuence Policy Processes: A Literature Review (Overseas Dev. Inst., Working Paper No. 249, 2005). Although the Ukrainian disability advocates discussed at the conference received international support, their goals and operating methods were entirely oriented towards lobbying the Ukrainian state or effecting change in public opinion in the Ukraine. Likewise, the Kimberly Process, raised in the conference as an example of the "penetration of standards," is assimilable to models of corporate and civic interaction with governments. Winchester notes the limits within which NGOs continue to operate: "Notwithstanding enhanced influence, non-state actors must still appeal to states to act, or seek states' approval or at least acquiescence." Winchester supra note 5 , at 22 . This seems equally true of such examples as NGO involvement in the creation of the International Criminal Court and the Landmines Convention. Cf. Ku, supra note 48, at 116-17. Lobbying is entirely 
new era of global transnational citizen activism that is radically transforming the landscape of international diplomacy[,]" 56 accredited delegates (including 114 heads of state) were outnumbered ten to one by NGO members, farmers, businessmen, and indigenous people "all of whom were in Rio de Janeiro to lobby delegates and attempt to influence conference declarations." of participation within the existing state system. ${ }^{58}$ Yet discourse has long since turned to NGOs' accountability, ${ }^{59}$ as if they already had a significant governance role; this is true even of the significant literature critical of the rise of NGOs on democratic legitimacy grounds, which raises such criticisms precisely because it accepts the significance of the shift. Numerical proliferation-evidence of change-may interfere with critical analysis of how, precisely, NGOs constitute functional governance in relation to the state. ${ }^{60}$ None of this is to diminish the important work performed by NGOs or the validity of scholarly analysis of that work; it is only to suggest that interpreting this work as governance may not meaningfully describe it or contribute to our understanding of it.

\section{Business Self-Regulation}

In many ways, the claim that global business and consumer activists are developing their own regulatory environment is the most compelling locus for global governance; ${ }^{61}$ here too, however, the very act of focusing on these actors may draw attention away from others. So for example, at the conference, the Baku-Tbilisi-

compatible with governance models, of course-my point is, simply, that hardly suggests a novel shift.

56. Winchester, supra note 5, at 10 (citing Hilary French, Reshaping Global Governance, in STATE OF THE WORLD 2002, at 187 (Linda Starke ed., 2002)).

57. Winchester, supra note 5, at 10. But see Mathews, supra note 34, at 55 (noting that "[t] he tiny nation of Vanuatu turned its delegation over to an NGO ... making itself and the other sea-level island states major players in the fight to control global warming").

58. Mann, supra note 3, at 144 (Activists "use emerging global networks of communication and NGOs, and they focus energies on the UN as well as their own state. However, most contending actors demand more regulation by their own nation-state through its legal or welfare agencies ....").

59. See Szporluk, supra note 54, at 349 (discussing accountability issues).

60. Cf. Antonio Gramsci, Prison Notebooks (1992) (discussing cultural hegemony and civil saciety's interrelationship with the state); JUrgen Habermas, The Structural Transformation of the Public Sphere: An Inquiry into a Category of Bourgeois Society (1989) (discussing the concept of a public sphere); KarL PopPer, THE OPEn SOCIETY And ITS EnEmies (1945) (discussing the function of civil society).

61. See, e.g., Tim Bartley, Certifying Forests and Factories: States, Social Movements, and the Rise of Private Regulation in the Apparel and Forest Products Fields, 31 PoL. \& Soc'y 433 (2003); Errol Meidinger, Competitive Supragovernmental Regulation: How Could It Be Democratic? 8 CHI. J. INT'L L. 513 (2008). 
Ceyhan (BTC) pipeline was presented as an instance of corporations taking a leading role in structuring states' legal regimes. In a deal with a British Petroleum-led consortium, Azerbaijan, Georgia, and Turkey agreed to enforce legal regimes whose evolution they did not control and signed on to supervisory processes like the Extractive Industries Transparency Initiative. ${ }^{62}$ It is quite a story: the corporation as lawmaker more sovereign than the state, now figuring as "just another player" and not the decisive one.

But someone taking even a cursory glance at a map might wonder at the curious route of BTC. Owing to the impasse over Nagorno-Karabakh, Armenia's frontiers with Azerbaijan and Turkey are closed, so the pipeline had to be routed over Georgia. There is a shorter route through Iran, but this is unacceptable to the United States. Georgia's littoral is closer still, but Turkey insisted tankers not sail through Istanbul ${ }^{63}$ and diverted the pipeline to the Mediterranean, which entitles it to billions of dollars in transit fees. BP's consortium was not powerless, but its investment was determined by classic geostrategic concerns. The only reason BTC got built at all is that the United States pressed for a route to break the Russian and Iranian lock on transshipment of Central Asian oil; business decisions alone cannot explain BTC's route, or even its existence. The consortium is like a ship struggling to chart a course through rough seas: a savvy captain can steer his vessel safely through and even turn a profit, but it is a foolish captain who forgets, even for a moment, where he is, or who sails straight into the storm. ${ }^{64}$

Unquestionably global economic forces are in flux, and corporate networks exert enormous influence on their own regulatory environment, but this merely returns us to the question of baselines: when have states ever had control of their economic destinies? The nineteenth and early twentieth centuries were marked by depressions on a pan-European or global scale, ${ }^{65}$ while within and across given economies, the largest companies were enormously influential. When one recalls the enormous foreign investments of the Westphalian past, their interconnection with geopolitics-the

62. Cf. Extractive Industries Transparency Initiative, http://eitransparency.org (last visited Oct. 4, 2008). Only Azerbaijan is a Candidate Country under the process.

63. See Bahman Aghai Diba, Baku-Ceyhan Pipeline: The Biggest Development In the Caspian Sea Since the Collapse of USSR, Sept. 17, 2002, http://www.payvand.com/news/02/sep/1060.html; Azerb .com, Baku-Tbilisi-Ceyhan Pipeline, http://www.azerb.com/az-btc.html (last visited Nov. 8, 2008). There are real environmental and commercial concerns, but the point is that Turkey's interpretation proved decisive.

64. Cf. Anderson, supra note 49, at 37 ("[T] he global order that the superpower underpins is the one in which the NGOs swim as fishes in the sea.").

65. League of Nations, The Course and Phases of the World-Economic Depression 274-98 (1931). 
Vereenigde Oostindische Compagnie, the Ottoman Public Debt Administration, the Suez Canal, United Fruit-and the ambiguous position this put minor powers in, one wonders why exactly we think that state-corporate interactions like BTC are fundamentally different; ${ }^{66}$ why, that is, that they suggest the state is weakening, rather than that there have always been strong and weak states, both in the Westphalian past and today. Indeed, if one considers the extraordinary rise in the power of the state since the early nineteenth century-the increase in its tax base, bureaucracy, and responsibilities - it is possible that the contemporary state has more control over the economy than its notionally more sovereign counterpart. ${ }^{67}$

True, we are several decades into a shift from dirigisme toward free-market liberalization, which logically tracks with diminution of state control and a rise in horizontal regulation by business and capital markets; this recommends an interpretative frame open to the possibility that this is a correction. ${ }^{68}$ States retain enormous authority to regulate and define business both within and between their jurisdictions, and there may be predictable limits to any shift. Development theory suggests the fundamental importance of clear norms about property and contract, which may imply decisional hierarchy ${ }^{69}$ and thus a minimum state function, which markets may find difficult to substitute.

66. The economic interpenetration of the industrial powers prior to the First World War is axiomatic. Cf. Norman Angell, The Great Illusion (1913) (discussing economic interpenetration and its pacific effects); Hirst \& Thompson, supra note 44, at 274-86. The standard turn-as with NGOs-is to emphasize the unprecedented (and undeniable) quantitative growth. See Matthews, supra note 34, at 52 ("Today's powerful nonstate actors are not without precedent. The British East India Company ran a subcontinent, and a few influential NGOs go back more than a century. But these are exceptions. Both in numbers and in impact, nonstate actors have never before approached their current strength. And a still larger role likely lies ahead.") Thus, discussing Angell's thesis, one participant in the conference suggested the vastly greater volume and speed of trade today is the decisive difference. I am not competent to evaluate this entirely sensible suggestion, though I gather the whole point of the distinction-apart from its possible truth-is that as a percentage of total trade, the present levels of transnational commerce are not unprecedented, and were last achieved in an era we identify with strong state sovereignty. (Note too, in Matthews, the element of prediction.)

67. I mean more control in terms consistent with classical theory of the sovereign state, and not solely by virtue of participation in international institutions in the way theorists like Raustiala argue, though these effects may also be occurring. See Kal Raustiala, Rethinking the Sovereignty Debate in International Economic Law, 6 J. INT'L ECON. L. 841 (2003).

68. Calls for increased state regulation in response to the financial crisis may signal the end of this period.

69. See, e.g., Hernando De Soto, The Mystery of Capital: Why Capitalism Triumphs in THE West and Fails Everywhere ElSE (2000). Recent responses to the financial crisis suggest that self-regulation has not displaced pervasive state regulation (including inter-state cooperation) in shaping markets. 
These are problems of time. It may be, in other words, that global governance theory as formulated has disinclined its students to sufficient study of historical and theoretical evidence for the strengthening of the state over time which a full embrace of a more atemporal idea of global governance would recommend. Difficulty accounting for the possibility of predictable limits is but one consequence of an definitional frame biased toward indicia of novelty. It is not clear if the changes underlying proofs of global governance have occurred only recentlysince the Second World War and especially in the last three decades ${ }^{70}$ —or are a process that roughly tracks the modern era, ${ }^{71}$ a timeframe that includes the rise of the state itself.

\section{Supranationalism}

Lurking behind many global governance claims is the European Unionundoubted proof of post-national, post-sovereignty governance. ${ }^{72}$ Arguably, though, the soft-power experiments of the EU present little challenge to the state system, and instead point to a conceptual problem with the theory's definition; the $\mathrm{EU}$ is not a governance organ in the broad sense, but in the narrow one-a kind of government. As the EU acquires the powers of states, it becomes more statelike-accreting constitutions, elected bodies, fiscal powers, regulatory authority, and a foreign policy. The forging of a "state-like" EU coexisting and overlapping with traditional states would (already does) constitute a novel, world-historical realignment of power that richly deserves to be studied-but it would also be in many ways a state, perhaps best understood as consolidated, rationalized Westphalianism. This may be a general problem with the approach to power in theories of global governance-especially, perhaps, theories of network disaggregation-which seldom articulate how, once meaningful power is trans-

70. See generally Tagi Sagafi-neiad, The UN and TRansnational Corporations: From Code of CoNDUCt to Global Compact (forthcoming 2008) (discussing the advent of globalization in the 1980s).

71. Mark W. Zacher, The Decaying Pillars of the Westphalian Temple: Implications for International Order and Governance, in Governance Without Government: Order and Change IN WORLD Politics 58, 59 (James N. Rosenau \& Ernst-Otto Czempiel eds., 1992) ("[The growth of international cooperation] is a process whose roots can be traced back at least to the beginning of the industrial revolution, but it has only been since 1945 that it has accelerated so as to have a marked effect on the international order."); Globalization, STANFord EnCYClopedia OF PhILOSOPhy (rev. ed. 2006), http:// plato.stanford.edu/entries/globalization/.

72. See, e.g., Christopher J. Borgen, Whose Public, Whose Order? Imperium, Region, and Normative Friction, 32 YALE J. INT'L L. 331 (2007). At this conference, Professor Milman-Sivan discussed the European Union's governance role. 
ferred into non-state actors' hands (or to networks of states and supranational institutions), they will not discover incentives to preserve and expand that power which may, in effect, convert them into state-like entities themselves. ${ }^{73}$ Such changes would still be consequential, but better accounting for Westphalian continuities would move global governance theory toward a less expansive, though no less important interpretation of real change.

\section{The Thinness and Directionality of Global Governance's Evidence}

These examples, few and incomplete as they are, are also perhaps hopelessly substantive, and my point is not to contest the fact of shifts in power (and certainly not the fact of change), but to suggest imbalances that may arise out of the nature of the project. I think these have to do with the interpretative frame: the most problematic element of global governance theory may be its starting point that the modern state is in significant transition under pressure from an array of mechanisms and processes. The proffered evidence suggests real problems with identifying the timeframe in which to make claims about such changes and with identifying them as challenges. If global governance is a recent phenomenon, how do we explain the occurrence of disaggregated non-state action in earlier eras? $?^{74}$ If global governance is occurring over centuries, then why are the evolving state apparatus and interstate system not themselves a robust response to those changes? Evidence of actual exist-

73. Cf. Rosenau, supra note 8, cited in Winchester, supra note 5 , at 18 (referring to the "increasing" and "irreversible" disaggregation of authority). But what if it is the nature of power to aggregate itself? Much political philosophy and human history support the proposition that actors and institutions tend to accumulate power. See TilLY, supra note 38 (discussing dominance by coercive and capital-holding elements in competition for control of state); cf. Lord Acton, Letter to Bishop Mandell Creighton, in LifE AND LetTers of MANDELL. CREIGHTON 371-72 (Glehn Creighton \& Louis Creighton eds., 1906). In contradistinction, global governance may prove too optimistic about the capacity for disaggregated networks - which are supposed to arise and reform functionally-to perform defined governance tasks without adopting a power logic. It may be, in other words, that disaggegrated network theory does not describe a stable equilibrium, but only a mechanism of transfer between equilibria. The new actors might not be states-they might be a new Hanseatic League, non-territorial actors, institutions, cartels-but to the degree their interests competed with other states, they might find it necessary, in defending those interests, to compete directly with states and in effect displace them by becoming them. (This logic explains the rapid spread of the modern, European state model under industrialism and decolonization, for example.) The point, however, is that global governance theory, having incorporated assumptions about change and often disaggregation into the definitional heart of the model, may not be conceptually equipped to consider this objection.

74. Cf. Anderson, supra note 49, at 4-8 (identifying abiding instances of inherently transborder, non-state actors interacting with the ruler in the Western Christian tradition, though noting also their profound differences from modern NGOs). 
ing global governance can be as thin and imbalanced as its definition is expansive and unrestrained, relying on the observation that more NGOs, multinational corporations, institutions and networks exist-that change is happening-and the invocation of speculative trajectories. Focused as it is on processes of change--and often on non-state actors - global governance may be conceptually inattentive to evidence of the state's capacity for dynamic reconstitution. ${ }^{75}$

I am not defending a monolithic State. The insight that states are social constructs teeming with disparate and contesting elements is not new; ${ }^{76}$ states and the state system are complex, and always have been. That is the point: even in the high Westphalian moment, whenever that was, states were not monolithic actors, but complex, internally contradictory, teeming multiplicities with overlapping affiliations that reached outside borders to like-minded actors inside other supposedly sovereign units. ${ }^{77}$ But if the state never was a centralized, unitary creature, there is no necessary reason to interpret present proofs of heterogeneity or dynamic response as a relative decline in state power or a novel disaggregation. This continuing plurality and multiplicity does not necessarily change the social reality of the constructed state as an actor fulfilling identifiable functions--some of which may, even as they change in their particulars, reflect a patterned maintenance of certain governance functions: a core state. ${ }^{78}$

\section{The Most Annoying Question: Is There an Irreducible State?}

Rather than replicate an imbalanced definitional logic, the most comprehensive research explores the balance between "governance by government" and "other governance" by asking if there are any irreducible or sticky elements of the

75. Dynamic change in response to environmental shifts can produce the functional equivalent of stasis - the maintenance of a stable set of relationships to other actors.

76. See, e.g., Arthur F. Bentley, The Process of Government: A Study of Social Pressures (Belknap Press 1967) (1908); Nicholas Lemann, Confict of Interests, NEw Yorker, Aug. 11, 2008, at 86 (discussing BENTLEY).

77. Certainly, global governance theorists recognize this. See generally K.J. Holsti, Governance Without Government: Polyarchy in Nineteenth-Century European International Politics, in GOVERNANCE WITHOUT GOVERNMENT, supra note 71 , at 30, 57 (discussing complex governance in the nineteenth century).

78. Cf. Raustiala, supra note 67 , at 843 (discussing sovereignty-strengthening functions of international institutions, and calling this "a line of thinking that rejects the dominant thinking on sovereignty and institutions"). 
state. ${ }^{79}$ This seems intuitively plausible: states have proven considerably more durable phenomena than most private organizations (other than religions). ${ }^{80} \mathrm{~A}$ "Westphalian continuity corollary" would suggest that a) even in conditions of dynamic change, b) states demonstrate persistent, possibly irreducible powers, c) which may be necessary functions under international conditions of anarchy.

Are there irreducible functions of the state under present conditions? ${ }^{81}$ From at least the late Westphalian phase after industrialization, state-like entities ${ }^{82}$ generally:

- exercise (near-)monopolies of violence;

- control taxation, defense, basic security and citizenship policy;

- operate formally legitimated adjudicative, legislative, and executive organs;

- exercise near-exclusive decisional access to international institutions; ${ }^{83}$

- are both major property owners and property rule makers;

- are both major market players and market regulators; and

- possess relatively captive labor and consumer pools. ${ }^{84}$

In addition, many states have populations that, rationally or otherwise, are willing to die or kill for the state project. This list is too long to be a true minimum ${ }^{85}$ there are many states that do not fulfill these criteria-but functions related to

79. For example, Slaughter acknowledges that only states can provide certain forms of legitimacy. Anne-Marie Slaughter, A New World Order (2004).

80. Hosti, supra note 77, at 31 ("In terms of endurance, the state is far safer than is a typical business firm."). Argentina, for example, was launched as an independent enterprise in 1816 and has been operating continuously ever since.

81. Obviously the state is not essentially irreducible, since there were times in recorded history when states did not even exist in anything like the form we now know. I restrict myself to conditions of complex, industrialized societies with communications and trade networks - conditions likely to persist.

82. That is, organized political entities controlling a territory and population. Cf. Convention on the Rights and Duties of States, Dec. 26, 1933, 49 Stat. 3097, Treaty Series 881, http://avalon.law.yale .edu/20th_century/intam03.asp. An overly narrow definition of the state-one that might exclude, say, historic Saxony because it was part of a larger unit called the Holy Roman Empire, despite its having its own government and military-does not strike me as terribly useful. My conception and the following list are influenced by MaX Weber, Politics as a Vocation (1919).

83. Milman-Sivan, supra note 29 , reminds us that the International Labour Organization is almost unique in having non-state representatives in its governance, and even these are appointed by the states. Constitution of the International Labour Organization art. 3.5, available at http://www.ilo.org/ilolex/ english/constq.htm. (Some human rights treaty commission members serve in a personal capacity; they are also appointees.)

84. See Dauvergne, supra note 42, at 588 (calling migration controls "last bastion" of sovereignty). This is not the case for production and capital, which are much more mobile than human populations.

85. There is no reason to think labor markets must be as restricted as they now are, for example. 
defense, basic security, taxation, citizenship policy and even-though it goes to the very heart of global governance-maintenance of basic legal and government structures are a plausible minimum. ${ }^{86}$ As much global governance literature acknowledges explicitly or implicitly, ${ }^{87}$ there is little evidence that states are surrendering these core functions, ${ }^{88}$ or even disaggregating them ${ }^{89}$ in any way that meaningfully limits the role of states to act individually or in concert qua states-that is, as they long have. Moreover, there may be a categorical displacement effect. Some state-like entity exercises these powers almost everywhere-not because it is normatively good, but because some entity inevitably will, and that entity, by virtue of performing those functions, takes on the qualities we associate with the state..$^{90}$ Even this short list would constitute a powerful limit on the scope of global governance, espcially if the effectuation of these minima continued to create the kind of gravitational effect on other functions as it did in the nineteenth century. ${ }^{91}$

86. This is the classical liberal "night watchman state." Cf. Robert Nozick, ANarchy, State, AND UTOPIA 26 (1974). I am not justifying a minimal state, rather suggesting it is a predictable minimal limit. $C f$. Anderson, supra note 49, at 37 ("The cause of global governance, and partnership with global civil society, looks much less attractive when security itself is an issue."); Strange, supra note 2, at 149 ("The need for a political authority of some kind, legitimated either by coercive force or by popular consent, or more often by a combination of the two, is the fundamental reason for the state's existence. But many states a re coming to be deficient in these fundamentals.").

87. A relative lack of global governance research on these core functions could constitute implicit acknowledgement that they are not areas as readily subject to a change logic.

88. But see Strange, supra note 2, at 149 (Declining state power "is less effective on those basic matters that the market, left to itself, has never been able to provide-security against violence, stable money for trade and investment, a clear system of law and the means to enforce it, and a sufficiency of public goods like drains, water supplies, infrastructures for transport and communications.").

89. Anne-Marie Slaughter, The Real New World Order, ForEign AfF., Sept.-Oct. 1997, at 183, 184 ("The state is not disappearing, it is disaggregating into its separate, functionally distinct parts. These parts-courts, regulatory agencies, executives, and even legislatures-are networking with their counterparts abroad, creating a dense network of relations that constitutes a new, transgovernmental order."). Slaughter's networks have real effects (including the strengthening of states' sovereignty, as Raustiala argues), but few of them go to the core functions of the state. Nor has the "competing notion of "human security ...creeping around the edges of official thinking" created meaningful inroads in state functions. Mathews, supra note 34, at 51.

90. Cf. Jennifer Hyndman, Conflict, Citizenship, and Human Security: Geographies of Protection, in WAR, Citizenship, TERritory (Deborah Cowen \& Emily Gilbert eds., 2007) (discussing security as the core good provided by the state). In some places the state fails dramatically to provide even these minima. We call those places "failed states," and it is an interesting question whether the existence of such places-and the fact that we interpret them as "failed"-argues for or against global governance as a predictive model, at least with reference to the many "functioning" states.

91. See generally Anderson, supra note 38; Stanford J. Shaw \& Ezel Kural Shaw, II History OF THE OtTOMAN EMPIRE AND MODERN TURKEy (1977) (describing interaction of military and Tanzimat reforms); THE Formation of National States IN WeStern EuROPE, supra note 35. 
This list is rough but not arbitrary; it is rationally related to human security in a world that lacks hierarchical ordering. The cosmopolitan fantasy of a post-Westphalian non-territoriality brunts up against the fact of humans' physicality, and their consequent, irreducible need to organize themselves on territory-the Hobbesian foundation of security and Maslowian heart of any governance project. ${ }^{92}$ Anarchy is not a Westphalian condition, but a given in all conditions short of global government; two or more bounded states create horizontality between them, which reinforces the need for local hierarchical structures to secure and govern the space and protect the people within, including their ability to reach out and interact. ${ }^{93}$

And as we have seen, beyond this minimum, during the timeframes most commonly proposed for global governance, states have acquired an extraordinary range of additional powers to regulate, redistribute, and coordinate among themselves, often in direct, dynamic response to changes in the broader socioeconomic environment-as, for example, in the nineteenth and early twentieth century, when increased mobility and passport regimes developed in parallel. Thus we confront an image of the state with a predictable, functional core, and a contingent but expansive set of powers around it. Such a view renders the state resilient, not static, able to mobilize and master changing resources, able to reinvent and redeploy itself. ${ }^{94} \mathrm{~A}$ Westphalian sensibility - the view that the state is an inevitable (not necessarily desirable) constructive consequence of large-scale populations living in conditions of anarchy-is necessarily skeptical about any project that does not adequately account for such possibilities.

92. Cf. Mann, supra note 3, at 136 ("State institutions, both domestic and geopolitical, still have causal efficacy because they too ... provide necessary conditions for social existence: the regulation of aspects of social life which are distinctively 'territorially centred."').

93. Brown, supra note 21 , at 22-23; cf. Hedley Bull, The Anarchical Society: A Study of ORDER IN WORLD POLITICS 13 (1977) (noting that in anarchical international society states are "bound by a common set of rules in their relations with one another and share in the working of common institutions"); see Friedrich Kratchowil, Preface, in International Organization: A Reader, at ix, $x$ (Friedrich Kratochwil \& Edward D. Mansfield eds., 1994) (noting "two distinct meanings. The technical meaning concerns the absence of central institutions .... But we also use the concept of anarchy to characterize a situation in which order itself is lacking. . .which comes close to the Hobbesian 'war of all against all[,]"' and noting the two meanings' incompatibility.) I align my observations with the technical meaning, consistent with Bull's: anarchy is not chaos or disorder.

94. Consider the response of European states to the challenge of international socialism-transformations such as centralized industrial planning, welfare policies, and broadened franchise - that left the state apparatus stronger than it had been, as well as more democratic. Nick Knight, Applying Marxism to Asian Conditions, in TWENTIETH-CENTURY MARXISM 141, 142-43 (Daryl Glaser \& David M. Walker eds., 2007); Jay A. Weinstein, Social and Cultural Change: Social Science for a DYNAMIC WORLD 272, 274-75, 277-78 (2d ed. 2005). 
Of course, global governance is to some extent constructed in contradistinction to traditions in political science and international relations that emphasize anarchy and a focus on states. ${ }^{95}$ To the degree global governance is simply an antidote to a Walzian reductivism ${ }^{96}$ or formalist legal analysis of the sovereign State, ${ }^{97}$ it is both welcome and, I would have thought, redundant. The standard defense of the "billiard-ball" approach to theorizing international relations-the need for parsimony in theory - seems unsatisfying: accounting for complexity does indeed render theory more complex, but that is an acceptable price. ${ }^{98}$ Still, in its quest for a more accurate complexity, global governance as theory risks substituting one simplification for another. By organizing and conceptualizing itself in opposition to state-centered anarchic theories of international relations and emphasizing the role of non-state actors, global governance risks overcompensating, discounting the meaningful contribution that theories of anarchy-which are generally static ${ }^{99}$ - make to our understanding.

One might well disagree with an interpretation relying on principles of anarchy, but global governance should have some theory of the minimal state. Asking about predictable minima is not essentialist, especially if by doing so we mean no more than to provide balance to the observation that change is always occurring and that the transit times for goods, people, and ideas have been reduced, which tells us nothing about their relationship to political entities that are themselves dynamically responsive. Recognizing that a predictable set of functions attach to the state-that

95. See, e.g., Benedicte Bull et al., Private Sector Influence in the Multilateral System: A Changing Structure of World Governance? 10 Global. GovernANCE 481 (2004) (adopting a neo-Gramscian critique of international relations theory).

96. Cf. Kenneth N. Walz, A Theory of International Politics (1979).

97. Cf. Henry Wheaton, Elements of International. Law 129 (Stevens \& Sons 1904) (1836) ("Every nation possesses and exercises exclusive sovereignty and jurisdiction throughout the full extent of its territory .... 'No state can, by its laws, directly affect, bind, or regulate property beyond its own territory, or control persons that do not reside within it, whether they be native-born subjects or not."').

98. Cf. Friedrich Kratchowil, Structures and Transformations, in InTERnational OrGanization, supra note 93, at 325, 325 ("By displacing power. . from its central place in a theory of international politics, subsequent theorizing could become less parsimonious and elegant. But. . the ideal of parsimony in theory building can prove doubly debilitating if not pursued with extreme caution.").

99. See Edward D. Mansfield, The Organization of International Relations, in INTERNATIONAL ORGANIZATION, supra note 93, at 1,2 ("[M] any studies of international relations argue that the underlying features of the international system have been much the same over time. They maintain that, at least in modern times, the global arena has been characterized by anarchy[,]" but critiquing such approaches as being insufficiently complex.). 
whatever exercises those functions will be something like a state-helps pragmatically shape predictions about the spread, and limit, of global governance.

Quite simply, theory must more adequately consider the possibility, not only of change but also of continuity. Global governance-definitionally oriented to the study of complex change and to the belief that there is not a central set of actors ${ }^{100}$ - may privilege assumptions which, right or not, color researchers' choice of subject, research design, and conclusions, and thus risks succumbing to the combination of profligacy and poverty inherent in its definition, reaching inaccurate conclusions that may overemphasize the significance of socioeconomic changes and underemphasize the state's resilient centrality in the global governance regime.

\section{Change We Believe in: The Exuberant Style in Global Governance}

Given that a serviceable, balanced atemporal definition of global governance is available that might avoid these risks, what accounts for the persistence of the temporal version?

Though its antecedents extend back farther, global governance as a discipline was largely constructed in the $1990 \mathrm{~s}^{101}$ —a period following the end of the Cold War that also saw the End of History, a New World Order, unipolarity, and the "irrational exuberance" of a New Economy. ${ }^{102}$ Appropriately, in a chronological if not intellectual sense, there was a greater than usual florescence of millennialism in those days. And indeed, within global governance, one can discern a phase in

100. Cf. Dingwerth \& Pattberg, supra note 8, at 192 ("[T] he notion of global governance starts from the assumption that a wide variety of forms of governance exist next to each other and that a hierarchy among these various mechanisms is hard, if not impossible, to discern: 'There is no single organizing principle on which global governance rests, no emergent order around which communities and nations are likely to converge. Global governance is the sum of myriad-literally millions of-control mechanisms driven by different histories, goals, structures, and processes .... In terms of governance, the world is too disaggregated for grand logics that postulate a measure of global coherence."'). Obviously, many global governance scholars acknowledge the important, even central role of the state-I speak only of a tendency.

101. See generally Anderson, supra note 49 (providing a periodization of global governance).

102. The internet was not only going to create a new economy, but a new concept of citizenship. Today, earnest "declarations of the rights of netizens," though a derivative species of global governance, frankly sound embarrassing. See, e.g., Michael Hauben \& Ronda Hauben, Netizens: On the History and Impact of Usenet and the Internet, FIRST MON., July 6, 1998, http://firstmonday.org/htbin/ cgiwrap/bin/ojs/index.php/fm/article/view/605/526; The Netizen Declaration of Citizenship (Oct. 29, 2004), http://linux.derkeiler.com/Newsgroups/alt.linux/2004-10/0674.html; Caslon Analytics Guide: Cyberspace Governance, Netizens? (Sept. 2007), http://www.caslon.com.au/governanceguidell.htm. 
which what was thought to be happening was not merely the proliferation of actors but the actual, absolute decline of the state. ${ }^{103}$

An intellectual movement is not defined by its origins, and global governance's center of gravity has shifted considerably. Indeed, part of the narrative self-identification of global governance as a field is, precisely, that it has moved on from this early, immature phase to embrace more grounded, technical analysis, including subfields whose work leads to very different conclusions about governance and the state. ${ }^{104}$ On this reading, global governance as a discipline seems to demonstrate, through its own temporal narrative, that it is decidedly, correctly unconcerned with passing intellectual fashions. I hope so, but I am skeptical about this narrative, in particular about the effects on perspective that come from forming, in the present moment, opinions about how far we actually are removed from our own past.

There is a general tendency, in people and their institutions, to overstate the relevance and meaning of recent and proximate things. This is evident, for example, in the tendency of general histories to devote much more text to recent than to distant events, but also in Freud's narcissism of small differences ${ }^{105}$ and in moral philosophy. ${ }^{106}$ Mere currency or salience does not actually imply greater importance, of course - this is logically insupportable—and indeed the vicissitudes of recent events flatten out in memory and analysis with the passage of time; shifts that feel world-historical inevitably, in the rush of other equally world-historical events, acquire a different, more tempered perspectival patina. This does not mean there are no epochal changes, no moments of rupture; it is simply that we

103. See Anderson, supra note 49, 12-27 (discussing the period 1989-1996 and 1996-2000); see, e.g., Saskia Sassen, Losing Control? Sovereignty in an Age of Globalization (1996); Christopher Schreur, The Waning of the Sovereign State, 4 European J. INT'L L. 447 (1993).

104. Anderson, supra note 49, at 35-36 ("[A] new and intellectually powerful assortment of scholars - impeccably liberal internationalist, wedded to global governance, but not at all wedded to the sanctity of global civil society - has already moved beyond the idea that global governance can or should be sought through global civil society. They are almost certainly right in viewing the global civil society movement as an element, but not the most compelling one, in creating global governance" and noting Anne-Marie Slaughter, Benedict Kingsbury, and Kal Raustiala.). See, e.g., Benedict Kingsbury et al., The Emergence of Global Administrative Law (N.Y. Univ. Pub. Law \& Legal Theory Working Papers, Paper 17, 2005), http://lsr.nellco.org/nyu/plltwp/papers/17/.

105. Sigmund Freụd, Civilization and its Discontents (James Stachey trans., W.W. Norton \& Co. 2005) (1930).

106. Cf. Adam Smith, The Theory of Moral Sentiments 157 (Cambridge Univ. Press 2002) (1761) ("[I]f [a man] would lose his little finger to-morrow, he would not sleep to-night; but, provided he never saw them, he will snore with the most profound security over the ruin of a hundred millions of his brethren[.]"). 
are predisposed to see more of them in our own time. We risk overstating the gravity of the moment, at every moment.

And I think, in some general but structural way, global governance reinforces this all-too-human tendency to overvalue the present, proximate, and novel; not only by its focus on change insufficiently tempered by longitudinal perspective, ${ }^{107}$ but also by encouraging an inaccurately monolithic image of the prior system, which in turn amplifies the sense that recent changes profoundly diverge from that system. In the worst and weakest instances, this monolithism creates a straw Westphalia against which the rise of the internet, NGOs, and global capital read as qualitatively more radical than they are, and thereby invoke a spurious globalism. ${ }^{108}$ But even in the best and most sober work, there is a risk of perspectival bias, if only arising from what is not written.

This dynamic may operate both within the broader definitional structure of global governance and, more narrowly, in encouraging confidence in the narrative claim that present scholarship has distanced itself from the more problematic researches of the 1990s. Despite its workman-like, technical quality, current scholarship in global governance may be profoundly marked by its own historically situated concepts-in particular in the very act of deciding what constitutes the proper object of study.

It is in this overvaluation of present change and undervaluation of temporal context that global governance exhibits a problematic susceptibility to fashion. Fashion, after all, is a disabling of longer-term temporal perspective-a collective enthusiasm by which we assign greater present value to a thing than, over time, we otherwise might. (Fashions in clothing, for example, change dramatically from year to year, yet dress codes exhibit considerably more stability over time; hems rise and fall, lapels widen and narrow, yet gender-differentiated clothing norms can be quite conservative.) The academic and policy realms are not immune to fashions. ${ }^{109}$ The puzzle, of course, is that significant shifts- like the spread of Western dress or the rise of international organizations-are, of neces-

107. Cf. Anderson, supra note 49 (periodizing global governance in ever shorter segments: up to 1989, 1945-1989, 1989-1996, 1996-2000, 1999-2000, and "9/11 and the Iraq war.").

108. Cf. McDougal \& Lasswell, supra note 12, at 3 (stating that "[e]ffective, comprehensive universality, despite the faint shadows of worldwide organization, does not now exist" and criticizing "the invocation of spurious universalism").

109. One example that straddles the worlds of academia and policy is the oft-noted tendency of aid and development agencies-including both NGOs and "beltway bandits"-to package whatever work they are doing as, say "rule of law" or "promotion of local ownership" in response to shifring fashion and funding priorities. 
sity, expressed through the Brownian motion of emphemeral trends, and the trick is to discern when something is just the one, and when it is both.

I do not wish to overstate the link between global governance's perspectival commitments to change and its present fashionability. After all, it is entirely possible for academic disciplines to adopt static methodologies, ${ }^{110}$ while temporary enthusiasms can also develop for permanent truths, as the periodic resurgence of religious sentiment or the historical determinism underpinning Marxism ${ }^{\text {III }} \mathrm{dem}$ onstrate. And of course, some things are fashionable - popular-for good reason. But this prompts me to suggest-in a purely speculative and general way-one further concern with global governance.

Some conceptual paradigms persist because they are powerfully generative of new, useful and persuasive thinking. Darwinian evolution, for example, continues to dominate our understanding of biology and fields beyond, largely due to its rigorous yet capacious explanatory power. Global governance, I fear, exhibits more capacity than rigor. Its popularity as an organizing concept derives more from its open, undefined, relatively content-free frame-its tendency to default towards the broad, ecumenical end of "governance"-and from the insights it allows rather than generates. ${ }^{112}$ Global governance is less an intellectual engine than an aggregator; almost anything could plausibly be described as global governance, and in this it represents more a sensibility than a true discipline. ${ }^{113}$

These are, admittedly, vast generalizations. I am surely guilty of excessive for-

110. At various times, history has adopted Braudelian longue duree perspectives, and classical economics was long focused on parsimonious, predictive theories, while the realist, statist international relations that much global governance is developed against were, to a large extent, attempts to develop theoretical models based on static elements. And of course the hard sciences are often expressly oriented towards discerning "laws."

111. Global governance's change narrative carries echoes of that tenet of Marxism according to which the state would wither away. That was wrong, but what was interesting was what it said about the project's millennial qualities and its inattention to the possibility of sticky elements in the global order. Is it possible that global governance-though much more sober and technical, and not a fashion only of the left-is the latest incarnation of this intellectual tendency? It would certainly be worth inquiring into the genealogical links between current global governance study and previous scholarly or political projects that envisioned a radical shift in the state-centered system; global governance may share common perspectives with world government enthusiasms of the interwar and early postwar periods. See World Government, Stanford Encyclopedia of Philosophy (rev. ed. 2006), http:// plato.stanford.edu/entries/world-government/; see also DEREK B. HEATER, A Brief History of CiTIZENSHIP 105-12 (2004) (on world citizenship).

112. A more positive way to frame this would be that global governance is a liberating perspective, freeing us from the artificial strictures of statist theory.

113. Cf. Dingwerth \& Pattberg, supra note 8, at 186 (describing a "global governance perspective"). 
malism; I certainly have taken the liberty of describing global governance theory and its definition almost as if these were Platonic entities, rather than distillations of countless scholars' efforts, and even though the communities interested in global governance are no better defined than the concept itself. So, I have set up my own little straw man. But if I am right that there is little uniting global governance as a field than a focus on change and an inclination to reject the narrow statism of classical international relations, what greater specificity could one possibly achieve? What could one say in praise or criticism of global governance as a field that would not merit immediate and justifiable objection for essentializing and ignoring complex sub-streams of scholarship? This immunity to generalization suggests something about the concept's coherence, and consequently, perhaps, its contribution. Global governance may simply encompass too much, and the risk in a Theory of Everything is that it does not actually explain much of anything. ${ }^{114}$

Perhaps you are thinking, "What a Luddite!" I do not think so. Much as I find the eternal verities compelling, I personally prefer the idea of living in exciting times. I understand the attraction of discovering that the world is changing profoundly and having a theory to explain it, as well as the urge to align one's interpretation with one's preferences. It is hard not to get swept up in the heady prospect of witnessing (even contributing to?) a world-historical shift in the organization of the planet. That does not necessarily make it true, of course. Or false: the effervescent quality of some global governance does not mean there is nothing going on. There are real changes in the way we view legal regulation ${ }^{115}$ and individual participation. ${ }^{116}$ Even fashions and bubbles can be harbingers of real change; there is a lucra-

114. Cf. Dingwerth \& Pattberg, supra note 8 , at 187 (" $[T]$ he rather careless use of the term global governance has contributed to rendering the academic discourse as confusing as it is and to profoundly limiting the cumulativeness of research findings."). Again, none of this is an attack on the extraordinary insights that individual scholars achieve. I intend a critique of the underlying structure, not of any individual work, any one of which might be-so many of which unquestionably arerigorous and valuable. Indeed, it follows from my critique that global governance as a construct, apart from its distorting potential, may contribute so little to inquiry that we would not expect it to greatly deflect the work of an otherwise competent researcher.

115. See Int'l Law Comm'n, Fragmentation of International Law: Difficulties Arising from the Diversification and Expansion of International Law, U.N. Doc. A/CN.4L.682 (Apr. 13, 2006).

116. See generally Thomas M. Franck, The Emerging Right to Democratic Governance, 86 AM. J. INT'L L. 46 (1992); Martin O. Heisler, Introduction-Changing Citizenship Theory and Practice: Comparative Perspectives in a Democratic Framework, 38 Pol. Scl. \& Pol. 667 (2005); Will Kymlicka \& Wayne Norman, Return of the Citizen: A Survey of Recent Work on Citizenship Theory, 104 ETHICs 352 (1994). 
tive (globalized) tulip industry, even though at times in history, tulips were a colossally bad investment. ${ }^{117}$ So too, perhaps, will it prove with global governance.

Denying change is not one of my projects, but neither is preferring (or opposing) disaggregated, globalized decision making for its own sake; my skepticism is interpretative, not political. ${ }^{118}$ What global governance as a discipline needs is more balanced inquiry into change and continuity ${ }^{119}$ —and with it, perhaps, an even more rigorous and sober sense of its own location in the long stream. The next time you are at a conference on global governance-and they occur quite often-if you hear someone declare the state "still relevant" or invoke "new modes of transnational citizenship," ask yourself how it will sound in ten years' time. How do you look in photographs from ten years ago? Because you know, fashion is a fickle thing.

Of course, maybe I will be the one who is embarrassed. Maybe in 2058, I will be boarding my flight to the annual World Governance Forum at Davos-sur-Merthis year's theme is "Remembering the Passport," and ever since my seminal 2010

117. Mike Dash, Tulipomania: The Story of the World's Most Coveted Flower and the Extraordinary Passions It Aroused 162-74 (1999); Charles MacKay, Extraordinary Popular Delusions and the Madness of Crowds (Crown Trade Paperbacks 1980) (1841).

118. I have made these arguments without reference to whether or not the changes collectively identified as global governance are a good thing or not, in normative terms. I wish to avoid that substantive thicket. A nyone familiar with my writing would know I am not a state sovereigntist-at least, I do not take existing states for granted. See, e.g., Timothy William Waters, The Blessing of Departure: Acceptable and Unacceptable State Support for Demographic Transformation, 2 Law \& ETHICs HuM. RTs. 221 (2008) (discussing the normative acceptability of secession and self-determination).

119. There are authors directly engaging this question. See KalEvi J. Holsti, TAming THE Sovereigns: Institutional Change in International Politics (2004); G. John Ikenberry, Taming the Sovereigns: Institutional Change in International Politics, ForeIGN AFF., Sept.-Oct. 2004, at 166, 166 (reviewing Holsti's book and stating that "[f]rom [Holsti's] baseline conception of a 'society of states' in which relations are regulated by Westphalian norms and institutions, he finds continuity and creeping complexity more than a sharp transformation toward a de-territorialized, borderless world."); see also Raustiala, supra note 67 (2003) (critiquing mainstream global governance theory's belief that state sovereignty is weakened by international institutions).

Other forms of balancing strike me as problematic. $C f$. JAMES N. ROSENAU, TURBulence IN World Politics: A Theory of Change and Continuity (1990). Rosenau's continuity-which includes locating present trends in accelerating stages of human evolutionary capacity-is a curious amalgam of an ultralongue durée and millennial optimism. See James N. Rosenau, Citizenship in a Changing Global Order, in GOVERNANCE WITHOUT GOVERNMENT, supra note 71, at 272, 278-79. I imagine a different balance, and one could do worse than draw initial, non-academic inspiration from an early, but profoundly ecological statement about the dynamic relationship of change and continuity Ecclesiastes 1: 6-7,9 (King James): "The wind goeth toward the south, and turneth about unto the north; it whirleth about continually, and the wind returneth again according to his circuits./ All the rivers run into the sea; yet the sea is not full; unto the place from whence the rivers come, thither they return again. / ...The thing that hath been, it is that which shall be; and that which is done is that which shall be done: and there is no new thing under the sun." 
article on the subject, I have been recognized as an indispensable if somewhat unreliable expert (though if you want to know the truth, I am going because I have never been to the Helvetic Archipelago before, and I am really looking forward to it). I will be delivering my paper entitled "Looking Back Fifty Years, I Couldn't Have Been More Mistaken.” Maybe; I certainly would not mind being around long enough to be wrong. But here is another prediction: Even if that happens, at the conference there will be some other idea that is fashionable. There always is. 